\title{
Ujian Akhir Madrasah Berbasis Android: Inovasi Mengatasi Minimnya Media Komputer MIN 1 Lebong
}

\author{
Yunsi Reva Agustina ${ }^{1}$ \\ yunsireva@gmail.com \\ Fakhrudin $^{2}$ \\ fakhruddinzidan@gmail.com \\ Muhammad Istan ${ }^{3}$ \\ muhammadistan@iaincurup.ac.id \\ ${ }^{123}$ Institut Agama Islam Negeri (IAIN) Curup
}

\begin{abstract}
This study sought to find a depiction of innovation made by the principal and teachers at MIN 1 Lebong concerning the madrasah's final exams academic year 2018/2019, amid the lack of media, by replacing the Computer-based madrasah's final exams (UAMBK) to Android-based madrasah's final exams (UAMBA). Thus, it called for an in-depth study to see its implementation. This study employed a qualitative approach. The data were collected through observation, interview, and documentation techniques, and the data were subsequently analyzed using Miles, Haberman, and Saldana' version of analysis, namely data reduction, data presentation, and drawing conclusion. This study concluded that the implementation of Android-based final exams, or the so-called UAMBA, was considered quite effective and efficient because it had several advantages including saving more budgets, being able to minimize the delay of UAM test packages, minimizing the occurrence of cheating during exams, making it easier for students, and making the exam results capably known quickly because the manual implementation of national exams was costly, wherein it demanded budgets for printing national exam packages and distributing those national exam packages.
\end{abstract}

Keywords: exams, learning innovation, android based media

Abstrak: Penelitian ini berusaha menemukan gambaran tentang inovasi yang dilakukan oleh kepala sekolah dan para guru di MIN 1 Lebong dalam ujian akhir madrasah Tahun 2018/2019 ditengah minimnya media dengan mengganti Ujian Akhir Madrasah Berbasis Komputer (UAMBK) menjadi Ujian Akhir Madrasah Berbasis android (UAMBA) sehingga perlu penelitian lebih dalam bagaimana impelentasinya. Penelitian ini menggunakan 
pendekatan kualitatif. Data dikumpulkan melaluai observasi, wawancara dan teknik dokumentasi selanjutnya dianalisis dengan prosudur versi Miles, Haberman dan Saldana yakni reduksi data, penyajian data dan penarikan kesimpulan. Penelitian memperoleh simpulan bahwa pelaksanaan Ujian Akhir berbasis Android yang sering dikenal dengan sebutan UAMBA ini dinilai cukup baik karena memiliki beberapa kelebihan diantaranya adalah lebih menghemat anggaran, keterlambatan soal UAM bisa diminalisir, meminimalisir kecurangan saat ujian, lebih memudahkan siswa, hasil ujian bisa diketahui dengan cepat karena pelaksanaan ujian nasional secara manual membutuhkan biaya yang tidak sedikit, penggunaan anggaran dimulai dari percetakan soal ujian nasional, pendistribusian ujian nasional yang membutuhkan dana yang lumayan besar.

Kata Kunci: Ujian akhir, Inovasi pembelajaran, media berbasis android

\section{PENDAHULUAN}

Mutu pendidikan merupakan salah satu isu sentral pendidikan nasional selain isu-isu pemerataan, relevansi, dan efisiensi pengelolaan pendidikan ${ }^{1}$. Perubahan UU No. 2 Tahun 1989 menjadi UU No. 20 Tahun 2003 tentang Sisdiknas diikuti dengan pemberlakuan kebijakan dalam penyelengaraan pendidikan yang bermutu. Kebijakan tersebut berfungsi untuk meringankan beban dan meningkatan partisipasi masyarakat dalam mencapai pendidikan minimal dengan mengutamakan pendidikan yang bermutu. Dalam Standar Nasional Pendidikan (SNP) pemerintah pusat melalui Badan Standar Nasional Pendidikan (BSNP) ada 8 (delapan) standar mutu pendidikan yaitu: standar isi, standar proses, standar penilaian, standar pendidik dan tenaga kependidikan, standar sarana dan prasana, standar pengelolaan dan standar pembiayaan ${ }^{2}$.

1 Irjus Indrawan, "Optimalisasi Politik Pendidikan Nasional Melalui Manajemen Berbasis Sekolah," Innovatio: Journal for Religious Innovation Studies 18, no. 1 (2018): 1-14; S. Suryana, "Permasalahan Mutu Pendidikan Dalam Perspektif Pembangunan Pendidikan," Edukasi 2, no. 1 (2017); Dwi Desi Yayitarina, "Regulasi Pendidikan Nasional Sebagai Upaya Meningkatkan Sumber Daya Manusia Memasuki Era Masyarakat Ekonomi ASEAN (Mea)," Jurnal Yuridis 3, no. 1 (2017): 66-82.

2 Ruyatul Hajar, "Implementasi Penjaminan Mutu Pendidikan Dalam Meningkatkan Kinerja Madrasah: Studi Di MTs Assurur Dan MTs Arrohmah Kota Tasikmalaya," Indonesian Journal of Education Management \& Administration Review 1, no. 1 (2018): 89-98; Saepul Anwar and Agus Fakhruddin, "Pelaksanaan Standar Penilaian Oleh Guru Pendidikan Agama Islam Di Sekolah (Studi Evaluatif Terhadap Guru PAI SMP dan SMA Di Bandung)," Jurnal Pendidikan Agama Islam-Taât ${ }^{T M}$ Lim 14, no. 2 (2016). 
Barlandaskan kepada delapan standar di atas, standar penilaian yang sering kali dijadikan tolok ukur mutu pendidikan, karena dari hasil penilaian bisa menunjukkan rentan angka keberhasilan atau kegagalan yang bisa menggambarkan bahwa bila hasil nilai memuaskan maka pendidikan itu dikatakan bermutu. ${ }^{3}$. Artinya ke tujuh standar tidak mengalami kelemahan namun sebaliknya jika nilai hasil menunjukkan penurunan maka pendidikan akan dikatakan tidak bermutu dan ketujuh standar lainnya akan menjadi keraguan akan keoptimalanya. Upaya merealisasikan penyelenggaraan pendidikan yang bermutu tersebut, telah ditetapkan visi pendidikan nasional, yaitu "terwujudnya bangsa, masyarakat, dan manusia Indoensia yang bermutu tinggi, maju dan mandiri"'.

Ketika membahas tentang mutu ada hal yang harus dicermati yaitu masalah indikator variabel-variabel pendidikan. Perspektif Kemendikbud mutu pendidikan ada tujuh variabel, yaitu: 1) nilai evaluasi belajar siswa, 2) angka mengulang (tinggal kelas), putus sekolah (drop out), dan lulusan 3) sarana prasarana pendidikan, 4) kualifikasi guru, 5) pendayagunaan sarana prasarana sekolah, 6) biaya pendidikan dan 7) partisipasi pihak orang tua dan masyarakat dalam penyelenggaraan pendidikan ${ }^{5}$.

Mencermati tujuh variabel di atas, dalam upaya melakukan evaluasi penilaian terhadap peserta didik guna untuk memajukan mutu pendidikan, terdapat beberapa jenis evaluasi yang digunakan oleh pihak sekolah diantaranya ujian harian, ujian tengah semester, ujian semester, ujian sekolah, dan ujian nasional. Disamping itu ada banyak faktor yang harus diperhatikan dalam upaya meningkatkan mutu pendidikan yang mempengaruhinya, salah satu faktor tersebut yaitu penggunaan teknologi informasi dan komunikasi ${ }^{6}$. Dalam dunia

3 Idi Warsah, "Islamic Psychological Analysis Regarding To Raḥmah Based Education Portrait At IAIN Curup," Psikis: Jurnal Psikologi Islami 6, no. 1 (June 1, 2020): 29-41, https://doi.org/10.19109/psikis.v6i1.3941.

4 Asbin Pasaribu, "Implementasi Manajemen Berbasis Sekolah Dalam Pencapaian Tujuan Pendidikan Nasional Di Madrasah," EduTech: Jurnal Ilmu Pendidikan Dan Ilmu Sosial 3, no. 1 (2017); Pupu Saeful Rahmat, "Peran Pendidikan dalam Menyiapkan Generasi Emas," Pendidikan Guru Sekolah Dasar S1 1, no. 01 (2016); Lukman Hakim, "Pemerataan Akses Pendidikan Bagi Rakyat Sesuai Dengan Amanat Undang-Undang Nomor 20 Tahun 2003 Tentang Sistem Pendidikan Nasional," EduTech: Jurnal Ilmu Pendidikan Dan Ilmu Sosial 2, no. 1 (2016).

5 Muhammad Fadil, "Penerapan Manajemen Berbasis Madrasah (MBM)(Studi Terhadap Karakteristik Input MBM di MIN 4 Pringsewu)" (PhD Thesis, UIN Raden Intan Lampung, 2017).

6 Adtman A. Hasan and Umi Baroroh, "Pengembangan Media Pembelajaran Bahasa

Arab Melalui Aplikasi Videoscribe Dalam Meningkatkan Motivasi Belajar Siswa," لسـانـا (LIS ANUNA): Jurnal Ilmu Bahasa Arab Dan Pembelajarannya 9, no. 2 (2020): 140-155; Febrianto Febrianto, Muhammad Rais, and Nurmila Nurmila, "Analisis Penerapan Media Pembelajaran Prezi Terhadap Hasil Belajar Siswa Kelas X TPHP Pada Mata Pelajaran Pengendalian Mutu Dalam Proses Pengolahan Di SMK Negeri 3 Takalar," Jurnal Pendidikan Teknologi Pertanian 2 (2018): 47-56. 
pendidikan salah satu penggunaan teknologi telah diterapkan pada pelaksanaan Ujian Nasional (UN).

Ujian nasional yang merupakan salah satu jenis sistem evaluasi standar pendidikan secara nasional untuk mengukur pencapaian peserta didik pada beberapa mata pelajaran tertentu dan persamaan mutu tingkat pendidikan antar daerah yang dilakukan oleh pusat penilaian pendidikan ${ }^{7}$. Dalam proses pelaksanaan ujian terdapat dua faktor yang harus diperhatikan, diantaranya faktor valid dan tidak validnya suatu penilaian. Adapun faktor tidak validnya suatu penilaian dapat dipicu dari tindakan kecurangan yang dilakukan oleh peserta salah satunya adalah menyontek.

Menyontek adalah melakukan ketidak jujuran dalam rangka meraih keuntungan ${ }^{8}$. Dellington menyebutkan bahwa perilaku menyontek adalah bentuk usaha-usaha dalam mencapai keberhasilan melalui cara-cara yang curang atau tidak jujur?. Dengan adanya perkembangan teknologi pada saat ini, salah satu cara untuk menghadapi permasalahan ketidak validan penilaian tersebut yaitu pelaksanaan ujian nasional tidak lagi menggunakan sistem ujian berbasis kertas atau Paper Based Test tetapi menggunakan sistem ujian nasional berbasis komputer atau Computer Based Test (CBT).

CBT merupakan sistem pelaksanaan ujian nasional menggunakan komputer sebagai media untuk melaksanakan ujian. UNBK ini pertama kali diperkenalkan oleh Menteri pendidikan pada tahun 2014 dan kemudian dilaksanakan secara online pada beberapa sekolah ${ }^{10}$. Selanjutnya pada tanggal 26 Januari 2017, Kepala Pusat Penilaian Pendidikan (Puspendik) Kemendikbud menyatakan, berdasarkan data terakhir terdapat 28.380 sekolah yang siap melaksanakan UNBK. Berdasarkan jumlah tersebut, sekitar 23-ribu sekolah siap menyelenggarakan UNBK di sekolahnya sendiri, sedangkan sisanya sekitar 4.500 sekolah menginduk ke sekolah lain ${ }^{11}$.

Secara konseptual sebelum menetapkan ujian berbasis komputer pihak sekolah harus memenuhi persyaratan kelayakan penyelengaraan UN berbasis komputer sesuai dengan peraturan BNSP 0031//BNSP/III/2015 tentang Prosedur Operasional Standar Penyelenggaraan Ujian Nasional Tahun Pelajaran

7 Mirna Santi and Andika Prajana, "Analisis Implementasi Ujian Nasional Berbasis Komputer Dengan Ujian Berbasis Kertas Di Smpn 3 Ingin Jaya Kabupaten Aceh Besar,” Jurnal Pendidikan Teknologi Informasi 2 (2018): 84-91; Syarif Hidayatullah, Ismail Marzuki, and Lukmanul Hakim, "UNBK: Transformasi Sistem Evaluasi Standar Nasional di Era Revolusi Industri 4.0," Jurnal Kajian Islam Dan Pendidikan Tadarus Tarbany 2, no. 1 (2020).

8 Warsiyah Warsiyah, "Perilaku Menyontek Mahasiswa Muslim," Wahana Akademika: Jurnal Studi Islam Dan Sosial 2, no. 2 (2016): 31-50.

9 Warsiyah.

10 Santi and Prajana, "Analisis Implementasi Ujian Nasional Berbasis Komputer Dengan Ujian Berbasis Kertas Di Smpn 3 Ingin Jaya Kabupaten Aceh Besar.”

11 Santi and Prajana. 
2014/2015 $5^{12}$. Ada beberapa aspek kriteria yang harus diperhatikan untuk mengukur tingkat kelayakan tersebut diantaranya meliputi ketersediaan infrastruktur, guru dan teknisi yang berkompeten, serta kesiapan mental dari siswa sendiri ${ }^{13}$.

Dewasa ini muncul perdebatan diberbagai kalangan masyarakat diantaranya mengenai kebijakan yang dikeluarkan pemerintah dibidang pendidikan dalam aspek evaluasi pendidikan melalui Surat Edaran Nomor 1, yaitu tentang pelaksanaan Ujian Nasional tahun ajaran 2016/2017 yang akan di prioritaskan melalui Ujian Nasional Berbasis Komputer (UNBK) atau Computer Based Test $(C B T)^{14}$. Namun bagi sekolah yang belum memiliki perangkat teknologi informasi yang memadai, tentu harus melakukan inovasi agar standar ujian yang telah ditetapkan oleh pusat dapat berjalan dengan baik, karena esensi dari inovasi adalah pembaharuan terhadap berbagai sumber daya sehingga dapat memberi manfaat bagi setiap orang ${ }^{15}$.

Berdasarkan penjelasan di atas, pada tahun ajaran 2018-2019 dalam sosialisasi pelaksanaan ujian tingkat madrasah tertanggal 25 Januari 2019 Kasi Pendis Kemenag Lebong Harta, M.Pd menghimbau agar seluruh sekolah melakukan inovasi dalam pelaksanaan UNBK yang pada sekolah madrasah pelaksanaannya diterapkan pada ujian yang disebut dengan UAMBN-BK yang meliputi tiga mata pelajaran yaitu Fiqih, Al-Qur'an Hadist, SKI, dan Aqidah Akhlak. Himbauan ini direspon positif oleh Kepala Madrasah Ibtidaiyah Negeri (MIN) 1 Lebong dengan melakukan inovasi model peralatan ujian dengan menggunakan android dengan pertimbangan sarana dan prasarana labor dan komputer belum tersedia. Sebagaimana dijelaskan oleh kepala sekolah ibu Yuni Darnis, S.Pd.I menyatakan bahwa:

"Inovasi ujian menggunakan android ini disamping bertujuan untuk menyeimbangkan kemajuan zaman dengan penggunaan teknologi pada tingkatan sekolah dasar agar keterbiasaan ujian pada tingkat menengah sudah terlatih nanti juga diharapkan mampu menekan praktek kecurangan atau menyontek sesama peserta ujian dan mampu menunjukkan efisiensi pelaksannan ujian menjadi lebih efektif sehingga mutu pendidikan akan lebih meningkat ${ }^{16}$.

12 Santi and Prajana.

13 Andika Prajana and Yuni Astuti, "Pemanfaatan Teknologi Informasi Dan Komunikasi Dalam Pembelajaran Oleh Guru SMK Di Banda Aceh Dalam Upaya Implementasi Kurikulum 2013," JINOTEP (Jurnal Inovasi Dan Teknologi Pembelajaran): Kajian Dan Riset Dalam Teknologi Pembelajaran 7, no. 1 (2020): 33-41.

14 Khaira Maulida and Wirdanengsih Wirdanengsih, "Upaya Yang Dilakukan Sekolah Di Daerah Terpencil Menghadapi Kebijakan UNBK," Jurnal Perspektif 2, no. 3 (2019): 243-250.

15 Idi Warsah and Nuzuar Nuzuar, "Analisis Inovasi Administrasi Guru Dalam Meningkatkan Mutu Pembelajaran (Studi Man Rejang Lebong)," Edukasi 16, no. 3 (2018): 294572.

16 Wawancara, 20 Februari 2020 
Berdasarkan pelaksanaan UAMBN-BK menggunakan android pada tahun ajaran 2018-2019 pada Madrasah Ibtadiyah Negeri 1 Lebong yang diikuti sebanyak 35 siswa dirasakan adanya unsur ketergesaan sehingga mengakibatkan siswa belum mengetahui secara keseluruhan pelaksanaan ujian tersebut, para orang tua banyak mengeluh karena keterbatasan ekonomi untuk membeli android sehingga meminjam dengan orang lain yang mengakibatkan anak-anak masih kaku dalam menngunakan android yang menuntut penjelaskan tata cara penggunaan dengan benar disaat proses ujian berlangsung yang mengakibatkan nilai Ujian Akhir Madrasah Berstandar Nasional menggunakan android pada tahun ajaran 2018-2019 mengalami penurunan dari pada nilai Ujian Akhir Madrasah Berstandar Nasional pada tahun ajaran 2017-2018 disaat masih menggunakan sistem ujian berbasis kertas. Hal tersebut merupakan indikator yang telah menunjukkan bahwa pelaksanaan ujian menggunakan android belum efektif, namun sebagai kepala madrasah yang professional Ibu Yuni Darnis, S.Pd.I masih akan tetap melaksanakan UAMBA menggunakan android dengan lebih meningkatkan lagi kematangan manajemen kepala madrasah dalam mempersiapkan ujian yang akan dilaksanakan pada april 2020.

\section{METODE PENELITIAN}

Metode penelitian merupakan rangkaian cara atau kegiatan pelaksanaan penelitian yang didasari oleh asumsi-asumsi dasar, pandangan-pandangan filosofis dan ideologis, pertanyaan dan isu-isu yang dihadapi oleh penelitian ini terutama tentang gambaran pelaknaan ujian dengan menggunakan android di MIN 1 Lebong, Bengkulu ${ }^{17}$. Penelitian menggunakan pendekatan kualitatif. Penelitian kualitatif adalah suatu jenis penelitian yang prosedur penemuan yang dilakukan tidak menggunakan prosedur statistik atau kuantifikasi ${ }^{18}$. Dalam hal ini penelitian akan menelaah tentang implementasi ujian berbasis android di MIN 1 Lebong dan hal-hal yang berkaitan dengan aktivitas tersebut.

Guna meperoleh data di lapangan digunakan dua pendekatan yakni interview dan pengamatan langsung (observasi). Kedua teknik ini merepresentasikan langkah ilmiah untuk mencapai tujuan dari penelitian. Observasi dan wawancara didesain berbasis pada paradigma filsafat naturalistik, yang mana prosedur pengaplikasiannya berbentuk observasi terbuka dan wawancara terbuka. Semua rekam jejak data mentah disimpan berdasarkan catatan lapangan dan rekaman video. Data yang diperoleh dari wawancara dan observasi selanjutnya diselaraskan dengan metode triangulasi agar data yang kredibel didapatkan ${ }^{19}$.

17 Punaji Setyosari, Metode Penelitian Pendidikan \& Pengembangan (Prenada Media, 2016); Muri Yusuf, Metode Penelitian Kuantitatif, Kualitatif \& Penelitian Gabungan (Prenada Media, 2016).

18 Lexi J. Moleong, Methodology of Qualitative Research (Bandung: Remaja Rosda Karya, 2010).

19 Elmar Hashimov, Qualitative Data Analysis: A Methods Sourcebook and The Coding Manual for Qualitative Researchers: Matthew B. Miles, A. Michael Huberman, and Johnny Saldaña. 
Sementara itu, analisis data mengadopsi model interaktif Matthew B. Miles, A. Michael Huberman, and Johnny Saldaña. Peneliti menganalisis data berdasarkan tahapan elemen analisis. Peneliti melakukan pengumpulan data berbasis pada observasi dan wawancara terbuka. Selanjutnya, peneliti melakukan pemadatan data atau biasa dikenal dengan istilah reduksi data. Setelah data direduksi, peneliti menyajikan data ${ }^{20}$. Dalam penelitian ini penyajian data diuraikan dalam bentuk narasi tentang imlementasi Ujian Menggunakan android pada pelaksannan Ujian Akhir Madrasah Berstandar Nasional Berbasis Komputer (UAMBN-BK) Tahun Pelajaran 2019-2020 di Madrasah Ibtidaiyah Negeri 1 Lebong. Pada tahapan terakhir, peneliti menyimpulkan data.

\section{HASIL DAN PEMBAHASAN}

Temuan yang berkenaan dengan temuan khusus mengenai upaya kepala madrasah dalam mempersiapkan pelaksanaan Ujian Akhir Madrasah Berbasis Android Tahun Pelajaran 2018/2019 di Madrasah Ibtidaiyah Negeri 1 Lebong disusun berdasarkan jawaban dari pertanyaan-pertanyaan penelitian melalui wawancara langsung, selain itu peneliti mendeskripsikan data dari hasil observasi dan studi dokumentasi.

\section{A. Persiapan Kepala Madrasah dalam Pelaksanaan Ujian Akhir Madrasah Berbasis Android}

Ujian Akhir Madrasah Berbasis Android adalah sistem pelaksanaan ujian akhir dengan menggunakan android sebagai media pengerjaan ujian. Hasil penelitian Batubawa dan Indra bahwa dasar hukum Ujian berbasis android mengacu pada peraturan ujian nasional konvensional yang berlaku dan merupakan aplikasi yang dapat memudahkan siswa-siswi dalam melakukan ujian nasional ${ }^{21}$. Begitu juga halnya, penyelenggaraan Ujian Akhir Madrasah Berbasis Android ini merupakan tahun ketiga dilaksanakan oleh Madrasah Ibtidaiyah Negeri 1 Lebong. Pada tahun pelajaran 2018/2019 pelaksanaan Ujian Akhir Madrasah Berbasis Android ini hanya dilaksanakan pada tingkat SMA dan SMK. Pada tahun 2018/2019 adalah awal dilaksanakannya 2018/2019 ini adalah perdana mlaksanakan Ujian Akhir Madrasah Berbasis Android (UAMBA) pada tingkat Madrasah Ibtidaiyah melaksanakan Ujian akhir madarasah dengan sistem ini. Mengingat sarana dan prasarana yang tersedia oleh pihak MIN 1 Lebong mampu mencukupi

Thousand Oaks, CA: SAGE, 2014. 381 Pp. Johnny Saldaña. Thousand Oaks, CA: SAGE, 2013. 303 Pp. (Taylor \& Francis, 2015); Kathryn Roulston, "Analysing Interviews," The SAGE Handbook of Qualitative Data Analysis, 2014, 297-312.

20 Matthew B. Miles, A. Michael Huberman, and Johnny Saldaña, Qualitative Data Analysis: A Methods Sourcebook. 3rd (Thousand Oaks, CA: Sage, 2014).

21 M. Diarmansyah Batubara and Evta Indra, "Perencanaan Dan Pembuatan Aplikasi Pengerjaan Ujian Nasional Tingkat SMP Berbasis Android," Query: Jurnal Sistem Informasi 2, no. 02 (2018): 11. 
kebutuhan pelaksanaan Ujian Akhir di Madrasah Ibtidaiyah Negeri 1 Lebong $^{22}$.

Berdasarkan hasil wawancara dengan kepala madrasah Yuni Darnis beliau mengatakan sebagai berikut:

"Dalam pelaksanaan Ujian Akhir Madrasah Berbasis Android (UAMBA) di Madrasah Ibtidayah Negeri 1 Lebong adalah satusatunya melaksanakan Ujian Akhir Madrasah Berbasis Android (UAMBA) di Madrasah Ibtidayah Negeri 1 Lebong di Kabupaten Lebong tingkat Ibtidaiyah". Pelaksanaan Ujian Akhir Madrasah Berbasis Android (UAMBA) dengan moda yang baru ini pada tingkat Madrasah Ibtidaiyah mengharuskan kepala Madrasah Ibtidayah Untuk bekerja ektra mempersiapkan pelaksanannya. Walau dari segi sarana dan prasarana Untuk melaksanakan Ujian Akhir Madrasah Berbasis Android (UAMBA) yang belum memadai ${ }^{23}$."

Menjelang Ujian Akhir Madrasah Berbasis Android (UAMBA), Kepala Madrasah Ibtidaiyah Negeri 1 Lebong sudah mulai melakukan beberapa antisipasi dan persiapan khusus. Persiapan khusus tersebut dimulai sejak awal semester ganjil sebelum akan dilaksanakannya pelaksanaan Ujian Akhir Madrasah Berbasis Android (UAMBA). Adapun persiapan yang dilakukan oleh Ibu Yuni Darnis selaku Kepala Madrasah Ibtidaiyah Negeri 1 Lebong dapat dilihat dari hasil wawancara sebagai berikut: "Dalam persiapan Untuk Ujian Nasional Berbasis Komputer tahun 2018/2019 ini ada beberapa persiapan yang saya lakukan yaitu :

1. Sarana dan prasarana yang akan dipakai dalam pelaksanaan Ujian Akhir Madrasah Berbasis Android (UAMBA), berupa:

a. 141 unit komputer tersedia (sesuai jumlah peserta ujian, dan selebihnya cadangan)

b. 4 ruang kelas

c. Proktor yang bertugas bertanggungjawab untuk mengendalikan server di madrasah.

2. Melatih mental peserta ujian Untuk menghadapi Ujian Akhir Madrasah Berbasis Android (UAMBA), berupa:

a. Motivasi yang selalu diberikan setiap sebelum dan sesudah mengikuti pembelajaran;

b. Bimbingan belajar (bimbel) tambahan, bimbingan tambahan Untuk mata pelajaran yang akan di ujiankan yaitu Bahasa Inggris, Bahasa Indonesia, Matematika, dan Ilmu Pengetahuan Alam; 
c. Bimbingan secara psikologis agar peserta ujian yang akan melakukan pelaksanaan UAMBA ini tidak gugup, berupa :

1) Pemahaman dan keyakinan mengenai pelaksanaan Ujian Akhir Madrasah Berbasis Android (UAMBA); dan

2) Teknis cara belajar.

d. Melakukan pelatihan ujian try out Ujian Akhir Madrasah Berbasis Android (UAMBA),

e. Simulasi Ujian Akhir Madrasah Berbasis Android (UAMBA);

f. Doa bersama". ${ }^{24}$

Dalam persiapan Ujian Akhir Madrasah Berbasis Komputer (UAMBK), tentulah butuh dana yang besar untuk penyedian perangkat komputernya. Penelitian Huzaimah dan Irfan menjelaskan bahwa aplikasi yang dirancang akan mempunyai tahapan dalam menjalankannya mulaidari login ke dalam aplikasi serta memilih interface yang tersedia. Uji coba pada score penilaian hasil ujian sudah dapat dilakukan secara otomatis pada android ${ }^{25}$. Sementara menurut kepala madrasah dari hasil wawancara berikut:

"Ujian Akhir Madrasah Berbasis Android dilatarbelakangi oleh besarnya dana yang harus dikeluarkan oleh sekolah jika mengguakan ujian berbasis komputer (UAMBK). Paling tidak dana yang harus dipersiapkan oleh pihak Madrasah Ibtidaiyah Negeri 1 Lebong, kurang lebih Rp. 2.000.000.000,- (Dua Milyar) baik itu perangkat Komputer seperti ruang komputer, monitor, keyboard, CPU, meja. Dalam pelaksanaan Ujian Akhir Madrasah Berbasis Komputer (UAMBK) perangkat lain seperti kursi peserta, dan juga meja, kursi proktor yang berada di depan yang sesuai dengan standar. Sementara jika menggunakan system ujian diganti dengan android (UAMBK) kita dapat menghemat biaya, hanya diperlukan 15 unit handphone android, yang digunakan untuk Ujian Akhir Madrasah Berbasis Android (UAMBA) dengan dilakukan secara sif-sifan, dan sebelum ujian berlangsung, saya pastikan perangkat handphone android yang akan digunakan tidak bermasalah". ${ }^{26}$

Hal ini juga di perkuat dengan hasil wawancara bersama dengan ibu Jumiati, S.Pd.I salah seorang guru MIN 1 Lebong sebagai berikut:

"Ruangan yang akan digunakan pada Ujian Akhir Madrasah Berbasis Android (UAMBA) setiap ruangan di isi 35 siswa dan ruangan ke empat di isi 36 siswa, secara berkala siswa melakukan

24 Wawancara, 25 Februari 2020

25 Fazriani Huzaimah and Dedy Irfan, "Rancang Bangun Aplikasi Ujian Online Pra Kompre Berbasis Android," VoteTEKNIKA: Jurnal Vocational Teknik Elektronika Dan Informatika 6, no. 2 (2018): 53-60.

26 Wawancara, 25 Februari 2020 
ujian dan juga nantinya ada proktor yang akan mengontrol jalannya ujian, proktor terdiri dari beberapa guru yang mengetahui sistem berjalannya computer pada saat ujian". ${ }^{27}$

Ujian Akhir Madrasah Berbasis Android (UAMBA) Tahun Pelajaran 2018/2019 di Madrasah Ibtidaiyah Negeri 1 Lebong adalah tahun kedua kali dilaksanakan, akan tetapi sudah mampu melakukan persiapan yang matang baik kepala madrasah, peserta ujian maupun para guru pembimbing. Ujian Akhir Madrasah Berbasis Android (UAMBA) ini di ikuti sebanyak 141 peserta ujian. Berikut nama-nama peserta Ujian Akhir Madrasah Berbasis Android (UAMBA) tahun pelajaran 2018/2019 di Madrasah Ibtidaiyah Negeri 1 Lebong:

Nama-nama Peserta Ujian Akhir Madrasah Berbasis Android (UAMBA) Tahun Ajaran 2018/2019 Pada Ruangan 1 (Satu) dengan jumlah laki-laki 19 perempuan 18 dan jumlah keseuruhan 37. Dalam persiapan pelaksanaan Ujian Nasional, kepala madrasah juga melatih mental dan memotivasi siswa agar mampu menghadapi ujian, hal ini dapat dilihat dari hasil wawancara bersama kepala Madrasah sebagai berikut:

"Peserta didik juga harus mempunyai mental yang kuat Untuk menghadapi Ujian Akhir Madasah Berbasis Andorid ini, supaya mereka yakin dan berssungguh dalam belajar, agar mereka memperoleh hasil yang maksimal, dan motivasi juga selalu di sampaikan kepada siswa yang akan ujian, karena Ujian Akhir Madasah Berbasis Andorid ini hasilnya langsung di kirim ke pusat dan tidak bisa diganggugugat, hasil ujiannya murni dari hasil yang mereka kerjakan pada saat ujian. Ujian Akhir Madasah Berbasis Andorid ini tidak ribet, tidak seperti ujian dengan tertulis yang setiap paginya harus jemput soal terlebih dahulu, setelah ujian selesai harus ngantar hasil ujiannya lagi ke dinas pendidikan. Jadi sekolah hanya menyediakan uniit komputer yang akan digunaakan pada saat ujian dan dibantu oleh proktor Untuk menjalankannya". ${ }^{28}$

Pernyataan kepala Madrasah tersebut juga disampaikan oleh Wakil Kepala Madrasah Bidang Tata Usaha berdasarkan hasil wawancara berikut: "Persiapan yang dilakukan kepala Madrasah selain persiapan sarana prasarana juga persiapkan mental terhadap siswa yang selau di berikan setiap paginya ketika baris sebelum masuk ke dalam kelas, kepala Madrasah selalu 
memberikan pengarahan dan motivasi kepada siswa, dan kami para guru pun di arahkan untuk selalu memotivasi siswa ketika jam pelajaran selesai" ${ }^{29}$.

Dalam menghadapi Ujian Akhir Madasah Berbasis Andorid tentunya siswa harus belajar dengan sungguh-sungguh dibantu oleh guru mata pelajaran yang akan diujikan. Hal ini sesuai dengan hasil wawancara dengan salah seorang guru mata pelajaran sebgai berikut:

"Siswa yang akan melaksanakan Ujian Akhir Madrasah Berbasis Android (UAMBA) harus menguasai mata pelajaran yang akan diujiakan agar mereka paham dan mampu mengerjakan soal-soal ujian yang harus mereka jawab dengan benar. Maka dari itu kepada menghimbau kami para guru mata pelajaran Untuk memberikan bimbingan belajar (bimbel) tambahan Untuk siswa yang akan menghadapi Ujian Akhir Madasah Berbasis Andorid. Kendala yang di hadapi pada saat memberikan bahan ajar kepada siswa yaitu siswa kurang memahami apa yang disampaikan gurunya kalau siswa disuruh baca buku, karena pada zaman sekarang ini, siswa lebih suka memainkan internet maka malas baca buku, jadi solusinya agar mereka tertarik mengikuti pelajaran khususnya pada mata pelajaran bahasa Indonesia, saya beri mereka video tentang cerita yang mendidik, misalnya cerita rakyat seperti malin kundang, setelah itu mereka ditugaskan Untuk mencari apa inti dari cerita tersebut, siapa aja yang berperan didalamnya, dan apa narasi yang terkandung didalam cerita itu. Nah dengan begitu mereka lebih suka mengikuti pelajaran". 30

Berdasarkan hasil wawancara di atas dapat diambil kesimpulan bahwa kepala madrasah dalam melakukan persiapan pelaksanaan Ujian Akhir Madasah Berbasis Andorid (UAMBA) tahun ajaran 2018/2019 ini dimulai dari mempersiapkan sarana dan prasarana seperti mempersiapkan perangkat komputer, ruang kelas, dan mempersiapkan proktor yang ahli dalam bidang komputer Untuk mengontrol jalannya Ujian Akhir Madrasah Berbasis Android (UAMBA). Kepala Madrasah juga melatih mental peserta ujian Untuk menghadapi Ujian Akhir Madrasah Berbasis Android (UAMBA), berupa motivasi yang selalu diberikan pada saat sebelum dan sesudah mengikuti pelajaran.

Kepala madrasah, wakil kepala madrasah bidang kurikulum dan juga wakil kepala madrasah bidang kesiswaan yang sekaligus sebagai guru di Madrasah Ibtidaiyah Negeri 1 Lebong, telah nenghimbau dan mengarahkan para guru untuk melakukan bimbingan belajar (bimbel) tambahan, khususnya pada guru mata pelajaran yang di ujikan yaitu Bahasa Inggris, Bahasa 
Indonesia, Matematika, dan Ilmu Pengetahuan Alam guna mempersiapkan pelaksanaan Ujian Nasional Berbasis Komputer dengan mengarahkan guru. Kepala madrasah juga melakukan bimbingan psikologis agar peserta ujian tidak merasa gugup, bimbingan itu berupa pemahaman dan keyakinan mengenai pelaksanaan Ujian Akhir Madrasah Berbasis Android (UAMBA) dan teknis cara belajar dalam menghadapi ujian. Mubarok dalam penelitiannya menjelaskan bahwa bimbingan belajar pra ujian akhir menjadi penting, sehingga diharapkan mereka lebih siap menghadapi ujian dan agar memperoleh nilai yang maksimal ${ }^{31}$.

\section{B. Proses Simulasi untuk Persiapan pelaksanaan Ujian Akhir Madrasah Berbasis Android}

Proses simulasi Ujian Akhir Madrasah Berbasis Android (UAMBA) di Madrasah Ibtidaiyah Negeri 1 Lebong yang dilakukan selama dua hari, yaitu pada tanggal 19 dan 20 Maret 2018, simulasi dilakukan sesuai mata pelajaran yang akan di ujian seperti Bahasa Indonesia, Matematika, Bahasa Inggris dan Ilmu Pengetahuan Alam. Nugraha menjelaskan bahwa simulasi ujian berbasis android menjadi penting dilaksanakan, agar dapat membandingkan efisiensi waktu dibandingkan dengan cara konpensional seperti menggunakan kertas kerja ${ }^{32}$. Berdasarkan hasil observasi, wawancara dan dokumentasi yang dilakukan peneliti berkaitan dengan proses simulasi Ujian Akhir Madrasah Berbasis Android (UAMBA) bahwa pada saat simulasi, siswa hadir pukul $06.30 \mathrm{WIB}$ dan setelah itu proktor membagikan kartu nama peserta simulasi. Pada saat di dalam ruangan, proktor memberi arahan pengerjaan soal-soal ujian kepada peserta simulasi, adapunhambatan yang di alami pada saat proses simulai berlangsung yaitu pada saat login dan pengisian soal ujian, sering terjadi login ulang, itu berarti tidak bisa melanjutkan pengisian soal berikutnya sehingga computer tiba-tiba padam. Hal ini disampaikan kepala madrasah dari hasil wawancara sebagai berikut:

"Siswa wajib mengikuti proses simulasi selama dua hari, siswa akan dibagikan tanda pengenal sebelum memasuki ruangan. Pada saat proses simulasi berlangsung kadang terjadi jaringan server yang tidak stabil dari pusat sehingga handpone andorid tiba-tiba padam pada saat pengerjaan soal, tetapi hal itu dapat diatasi dengan melaporkan ke proktor yang ada di ruangan ujian, nantinya proktor yang akan memberikan password lagi dan komputer bisa nyala kembali dan siswa dapat melanjutnya pengerjaan soal tanpa harus mengulang dari

31 Tyas Alhim Mubarok, "Pendampingan Persiapan Ujian Akhir Sekolah Pada Mata Pelajaran Bahasa Inggris Di Madrasah Aliyah Darul Muta’allimin Sugihwaras Nganjuk," Jurnal Pengabdian Dan Pemberdayaan Nusantara (JPPNu) 2, no. 1 (2020): 76-81.

32 Aditya Adjie Nugraha, Desi Kisbianty, and Benni Purnama, "Aplikasi Simulasi Try Out Ujian Nasional Pada Jurusan Multimedia Berbasis Android Pada SMKN 1 Kuala Tungkal," Jurnal Ilmiah Mahasiswa Teknik Informatika 2, no. 2 (2020): 137-147. 
awal. Kalaupun terjadi padam listik secara keseluruhan, tetapi kita tidak khawatir karena kita punya mesin genset yang selalu stanby dan secara otomatis computer bisa menyala kembali’"${ }^{\prime 3}$.

Hal senada disampaikan juga oleh salah seorang siswa yang mengikuti simulasi Ujian Akhir Madrasah Berbasis Android (UAMBA) dalam hasil wawancara sebagai berikut: "Proktor selalu memberi kami arahan pada saat simulasi berlangsung, jika ada kendala pada saat simulasi kami langsung lapor ke proctor agar di bantu menyelesaikan masalah yang terjadi. Kami diarahkan Untuk mengisi user name, password, dan mengisi token (kode tes ujian). Kami sudah tidak khawatir jika terjadi padam listrik karena sudah ada mesin genset yang secara otomatis akan menyalakan listrik kembali". ${ }^{34}$

Paparan data wawancara di atas dapat disimpulkan bahwa proses simulasi yang dilakukan pada tanggal 13 April 2020 yang sesuai dengan mata pelajaran yang akan di ujikan, maka seluruh siswa kelas VI (Enam) wajib mengikuti simulasi tersebut dan masing-masing siswa wajib menggunakan tanda pengenal yang telah dibagikan oleh proktor. Jika ada kendala pada saat proses simulasi berlangsung, siswa wajib lapor ke proktor untuk diberikan arahan agar bisa melanjutkan simulasi.

\section{Sistem dan Tata Tertib Pelaksanaan Ujian Akhir Madrasah Berbasis Android.}

Pelaksanaan Ujian Akhir Madrasah Berbasis Android (UAMBA) Madrasah Ibtidaiyah Negeri 1 Lebong dilaksanakan pada tanggal 13, 14, 15, 16 dan tanggal 17 April 2019. Berdasarkan hasil wawancara bersama ibu kepala Madrasah sebagai berikut:

"Sistem pelaksanaan Ujian Nasional ini mengacu pada Prosedur Oprasional Standar Penyelenggaraan Ujian Nasional Tahun Pelajaran 2018/2019. Pada prosedur pelaksanaan Ujian Akhir Madrasah Berbasis Android (UAMBA), panitia Ujian Nasional tingkat satuan pendidikan menetapkan ruang UAMBA dengan persyaratan, jadi kami selaku panitia Ujian Nasional sudah menetapkan ruangan UAMBA dan siswa tinggal melakukan Ujian Nasinal dengan baik dan benar". ${ }^{35}$

Dokumen yang diperoleh dari pihak MIN 1 Lebong yaitu Kepala Sekolah pada saat melakukan observasi tentang sistem dan tata tertib pelaksanaan Ujian Nasional di MIN 1 Lebong yang mengacu pada Prosedur 
Oprasional Standar Penyelenggaraan Ujian Nasional Tahun Pelajaran 2018/2019 sebagai berikut: ${ }^{36}$

a. Penyiapan Sistem UAMBA

1) Panitia UAM Tingkat Pusat mengembangkan sistem yang mencakup desain, program aplikasi, dan infrastruktur Untuk mendukung pelaksanaan UAMBA.

2) Panitia UAM Tingkat Pusat berkoordinasi dengan lembaga lain yang terkait Untuk melakukan evaluasi program aplikasi dan system UAMBA.

3) Panitia UAM Tingkat Pusat menyusun petunjuk teknis penggunaan (user manual) dan bahan pelatihan bagi tim teknis provinsi, tim teknis kabupaten/kota, proktor, teknisi, dan peserta UAMBA.

4) Panitia UAM Tingkat Pusat, Panitia UAM Tingkat Provinsi, dan Panitia UAM Tingkat Kabupaten/Kota berkoordinasi dengan Perusahaan Listrik Negara (PLN), penyedia layanan koneksi internet, dan berbagai lembaga terkait lainnya Untuk memastikan tidak ada gangguan menjelang dan selama pelaksanaan UAMBA.

b. Penetapan Tim Teknis UAMBA

1) Panitia UAM Tingkat Pusat membentuk Tim Teknis UAMBA

2) Pusat, terdiri dari unsur Puspendik, Pustekkom, PDSPK, Direktorat Pembinaan SMP, Direktorat Pendidikan Kesetaraan,Direktorat Pembinaan SMA, Direktorat Pembinaan SMK/MAK, Kemenag, dan Perguruan Tinggi Negeri.

3) Panitia UAM Tingkat Provinsi membentuk Tim Teknis UAMBA Provinsi, dan menyampaikan ke Panitia UAM Tingkat Pusat.

4) Panitia UAM Tingkat Kabupaten/Kota membentuk Tim Teknis UAMBA Kabupaten/Kota dan menyampaikan ke Tim Teknis UAMBA Provinsi, dan ke Tim Teknis UAMBA Pusat di dalam Panitia UAM Tingkat Pusat melalui Provinsi.

5) Tim Teknis UAMBA Pusat memasukkan data Tim Teknis UAMBA Provinsi dan Kebupaten/Kota ke situs web UAMBA, dan menyampaikan username dan password ke Tim Teknis UAMBA Provinsi dan Kabupaten/Kota.

c. Penetapan Sekolah/Madrasah Pelaksana UAMBA

1) Tim Teknis UAMBA Provinsi dan Kabupaten/Kota sesuai dengan kewenangannya, melakukan verifikasi dan menetapkan sekolah/madrasah pelaksana UAMBA dan sekolah yang bergabungg, dan sekolah/madrasah yang mengikuti UAM di tempat pelaksanaan UAMBA (menumpang).

2) Sekolah/madrasah yang dapat ditetapkan sebagai pelaksana UAMBA telah memenuhi persyaratan sebagai berikut: Telah 
terakreditasi; tersedia sejumlah komputer dan server sesuai kebutuhan; dan Memenuhi persyaratan teknis yang ditetapkan oleh Panitia UAM Tingkat pusat.

3) Tim Teknis UAMBA Provinsi dan Kabupaten/Kota sesuai dengan kewenangannya, memasukkan data sekolah/madrasah pelaksana UAMBA ke situs web UAMBA.

4) Sekolah/madrasah yang sudah ditetapkan sebagai pelaksana UAMBA diberi username dan password.

d. Penerapan Resource Sharing (Berbagi Sumber Daya) UAMBA

1) Sumber daya meliputi, sarana dan prasarana UAMBA (server, computer client, dan jaringan), sumber daya manusia Untuk pelaksanaan UAMBA (proktor dan teknisi).

2) Berbagi sumber daya dapat dilakukan lintas satuan pendidikan dan lintas jenjang pendidikan.

3) Berbagi sumber daya lintas satuan pendidikan dapat dilakukan antar sekolah dan madrasah, antar satuan pendidikan negeri dan swasta, antar satuan pendidikan formal dan nonformal.

4) Berbagi sumber daya lintas jenjang pendidikan dapat dilakukan antar sekolah.

5) Berbagi sumber daya dapat dilakukan dengan menggunakan sumber daya milik madrsah/perguruan tinggi atau instansi/lembaga pemerintah/swasta lainnya.

6) Berbagi sumber daya diatur dan dikoordinasikan oleh dinas pendidikan sesuai kewenangannya.

7) Biaya yang timbul dari pelaksanaan berbagi sumber daya menjadi tanggung jawab bersama antara satuan pendidikan yang menginduk dan satuan pendidikan pelaksana UAMBA, dengan mengacu kepada ketentuan biaya yang berlaku dalam Bantuan Operasional Sekolah (BOS) atau Bantuan Operasional Pendidikan (BOP), atau kesepakatan bersama sesuai dengan peraturan perundang-undangan yang berlaku.

e. Penetapan Tim Help Desk (Tim Layanan Bantuan)

1) Panitia UAM Tingkat Pusat, Provinsi, dan Kabupaten/Kota sesuai dengan kewenangannya membentuk tim help desk dengan kriteria sebagai berikut: Memiliki sikap dan perilaku disiplin, jujur, bertanggung jawab, teliti, dan memegang teguh kerahasiaan; Dalam keadaan sehat dan sanggup melaksanakan tugas dengan baik; Memahami POS penyelenggaraan UAM.

2) Tugas tim belp desk adalah: Memberikan informasi dan penjelasan terhadap pertanyaan atau pengaduan yang diterima dari pengawas, proktor, teknisi, atau panitia ujian; menerima, merekap, dan memberikan solusi terhadap pertanyaan, permasalahan dan/atau pengaduan yang terkait dengan pelaksanaan ujian sesuai petunjuk 
teknis (juknis) yang ditetapkan oleh Pelaksana UAMBA Tingkat Pusat dan berkoordinasi dengan tim belp desk di tingkat kabupaten/kota, provinsi, dan pusat sesuai dengan kewenangannya.

f. Kriteria dan Persyaratan Proktor, Teknisi, dan Pengawas

1) Proktor adalah guru atau tenaga kependidikan sekolah/madrasah dengan kriteria dan persyaratan: Memiliki kompetensi di bidang teknologi informasi komunikasi (TIK); Pernah mengikuti pelatihan atau bertindak sebagai proktor UAMBA; Bersedia ditugaskan sebagai proktor di sekolah/madrasah penyelenggara UAMBA; dan bersedia menandatangani pakta integritas.

2) Teknisi adalah guru atau tenaga kependidikan sekolah/madrasah dengan kriteria dan persyaratan: Memiliki pengetahuan, keterampilan, dan pengalaman dalam mengelola LAN sekolah/madrasah; Pernah mengikuti pembekalan atau bertindak sebagai teknisi UAMBA; dan bersedia menandatangani pakta integritas.

3) Pengawas adalah guru dengan kriteria dan persyaratan: Memiliki sikap dan perilaku disiplin, jujur, bertanggung jawab, teliti, dan memegang teguh kerahasiaan; dalam keadaan sehat dan sanggup mengawasi UAM dengan baik; bukan guru mata pelajaran yang sedang diujikan; tidak berasal dari sekolah yang sama dari peserta UAM; dan bersedia menandatangani pakta integritas.

g. Penetapan Proktor, Teknisi, dan Pengawas UAMBA

1) Penetapan Proktor dan Teknisi: Sekolah/Madrasah mengirimkan usulan calon proktor dan teknisi ke Panitia UAM Tingkat Provinsi atau Kabupaten/Kota; Panitia UAM Tingkat Provinsi atau Kabupaten/Kota melakukan verifikasi usulan calon proktor dan teknisi berdasarkan kriteria dan persyaratan yang ditetapkan; Panitia UAM Tingkat Provinsi atau Kabupaten/Kota menetapkan proktor dan teknisi yang telah memenuhi kriteria dan persyaratan; Panitia UAM Tingkat Provinsi atau Kabupaten/Kota menyampaikan surat penetapan kepada Panitia UAM Tingkat Provinsi Untuk diteruskan ke Panitia UAM Tingkat Pusat.

2) Penetapan Pengawas: Sekolah/Madrasah mengirimkan usulan calon pengawas ke Panitia UAM Tingkat Provinsi atau Kabupaten/Kota; Panitia UAM Tingkat Provinsi atau Kabupaten/Kota sesuai dengan kewenangannya menetapkan pengawas ruang ujian; Penempatan pengawas ditentukan dengan sistem silang (pengawas tidak mengawas peserta didiknya sendiri).

h. Pelatihan Teknis Pelaksanaan UAMBA

1) Panitia UAM Tingkat Pusat melakukan pelatihan teknis pelaksanaan UAMBA Untuk Tim Teknis UAMBA Provinsi dan Tim Teknis UAMBA Kabupaten/Kota. 
2) Tim Teknis UAMBA Provinsi atau Kabupaten/Kota melakukan pelatihan kepada proktor dan teknisi sekolah/madrasah.

i. Penyiapan Sistem UAMBA di Sekolah/Madrasah Pelaksana UAMBA

1) Penyiapan server lokal, client, jaringan LAN, jaringan WAN, instalasi sistem, dan instalasi aplikasi: H-21 sampai dengan $\mathrm{H}-15$.

2) Simulasi ujian dan gladi bersih sesuai dengan waktu yang ditetapkan oleh Tim Teknis UAMBA Pusat.

3) Sinkronisasi data: H-7 sampai dengan H-2.

4) Pencetakan Berita Acara, Daftar Hadir, dan Kartu Login: H-2 sampai dengan $\mathrm{H}-1$.

j. Prosedur Pelaksanaan UAMBA

1) Ruang UAMBA: Panitia UAM Tingkat Satuan Pendidikan menetapkan ruang UAMBA dengan persyaratan sebagai berikut: Ruang ujian aman dan layak Untuk pelaksanaan UAMBA; Sekolah/Madrasah pelaksana UAMBA menetapkan pembagian sesi Untuk setiap peserta ujian beserta komputer client yang akan digunakan selama ujian.

2) Penetapan proktor, pengawas, dan teknisi UAMBA; Setiap server ditangani oleh seorang proktor; Setiap 20 (dua puluh) peserta diawasi oleh satu pengawas; dan setiap sekolah/madrasah pelaksana UAMBA ditangani minimal satu orang teknisi dan setiap teknisi menangani sebanyak-banyaknya dua ruang UAMBA atau 40 (empat puluh) komputer client,

3) Setiap ruang UAMBA ditempel pengumuman yang bertuliskan "Dilarang masuk ruangan selain peserta ujian, pengawas, proktor, atau teknisi. Tidak diperkenankan membawa alat komuamikasi dan/atau kamera dalam ruang ujian."

4) Setiap ruang ujian dilengkapi denah tempat duduk peserta ujian dengan disertai foto peserta yang ditempel di pintu masuk ruang ujian; Setiap ruang ujian memiliki pencahayaan dan ventilasi yang cukup; Gambar atau alat peraga yang berkaitan dengan materi UAM dikeluarkan dari ruang ujian; Tempat duduk peserta UAMBA diatur sebagai berikut: Satu komputer untuk satu orang peserta ujian untuk satu sesi ujian; Jarak antara komputer yang satu dengan komputer yang lain disusun agar antarpeserta tidak dapat saling melihat layar komputer dan berkomunikasi; dan Penempatan peserta ujian sesuai dengan nomor peserta untuk setiap sesi ujian;

5) Ruang, perangkat komputer, nomor peserta Untuk setiap sesi ujian sudah dipersiapkan paling lambat 1 (satu) hari sebelum UAM dimulai.

k. Pengawas Ruang UAMBA, Proktor, dan Teknisi 
1) Pengawas ruang, proktor, dan teknisi harus menandatangani surat pernyataan bersedia menjadi pengawas ruang, proktor, dan teknisi sesuai dengan ketentuan yang berlaku.

2) Pengawas ruang, proktor, dan teknisi tidak diperkenankan membawa dan/atau menggunakan perangkat komunikasi elektronik, kamera, dan sejenisnya ke dalam ruang ujian.

3) Proktor dan teknisi dapat berasal dari sekolah/madrasah pelaksana UAMBA.

4) Proktor mengunduh password Untuk setiap peserta dari server pusat atau perguruan tinggi yang menjadi tim teknis provinsi.

5) Proktor mengunduh token untuk satu sesi ujian.

6) Proktor memastikan peserta ujian adalah peserta yang terdaftar dan menempati tempat masing-masing.

7) Proktor membagikan password kepada setiap peserta pada awal sesi ujian.

8) Proktor mengumumkan token yang akan digunakan Untuk sesi ujian setelah semua peserta berhasil login ke dalam sistem.

9) Proktor melaporkan/mengunggah hasil ujian ke server pusat

10) Proktor mencatat hal-hal yang tidak sesuai dengan POS dalam berita acara pelaksanaan UAMBA.

11) Proktor membuat dan menyerahkan berita acara pelaksanaan

12) dan daftar hadir ke Panitia UAM Tingkat Satuan Pendidikan serta mengunggah ke web UAMBA.

1. Tata Tertib Pengawas Ruang Ujian, Proktor, dan Teknisi

1) Di Ruang Sekretariat UAM: Pengawas ruang, proktor, dan teknisi harus hadir di lokasi pelaksanaan ujian 45 menit sebelum ujian dimulai; Pengawas ruang, proktor, dan teknisi menerima penjelasan dan pengarahan dari Ketua Panitia UAM Tingkat Satuan Pendidikan; Pengawas ruang, proktor, dan teknisi mengisi dan menandatangani pakta integritas;

2) Di Ruang Ujian, Pengawas ruang, proktor, dan teknisi masuk ke dalam ruangan 20 menit sebelum waktu pelaksanaan ujian Untuk melakukan secara berurutan:

a) Memeriksa kesiapan ruang ujian; Mempersilakan peserta ujian Untuk memasuki ruangan dengan menunjukkan kartu peserta ujian dan meletakkan tas di bagian depan ruang ujian, serta menempati tempat duduk sesuai dengan nomor yang telah ditentukan.

b) Membacakan tata tertib peserta ujian; Memimpin doa dan mengingatkan peserta Untuk bekerja dengan jujur; Mempersilakan peserta ujian Untuk mulai mengerjakan soal; 
c) Selama ujian berlangsung, pengawas ruang ujian wajib: Menjaga ketertiban dan ketenangan suasana sekitar ruang ujian; Memberi peringatan dan sanksi kepada peserta yang melakukan kecurangan; melarang orang yang tidak berwenang memasuki ruang ujian selain peserta ujian; dan Mematuhi tata tertib pengawas, di antaranya tidak merokok di ruang ujian, tidak membawa dan/atau menggunakan alat komunikasi dan/atau kamera, tidak mengobrol, tidak membaca, tidak memberi isyarat, petunjuk, dan/atau bantuan apapun kepada peserta berkaitan dengan jawaban dari soal ujian yang diujikan.

d) Lima (5) menit sebelum waktu ujian selesai, pengawas ruang memberi peringatan kepada peserta ujian bahwa waktu tinggal lima menit; dan setelah waktu ujian selesai, pengawas mempersilakan peserta ujian untuk berhenti mengerjakan soal; pengawas ruang ujian tidak diperkenankan membawa perangkat komunikasi elektronik, kamera, dan sejenisnya serta membawa bahan bacaan lain ke dalam ruang ujian.

m. Tata Tertib Peserta UAMBA

1) Memasuki ruangan setelah tanda masuk dibunyikan, yakni 15 (lima belas) menit sebelum ujian dimulai;

2) Memasuki ruang ujian sesuai dengan sesi dan menempati tempat duduk yang telah ditentukan;

3) Bagi siswa yang terlambat hadir hanya diperkenankan mengikuti ujian setelah mendapatkan izin dari Ketua Panitia UAM Tingkat Sekolah/Madrasah, tanpa diberikan perpanjangan waktu;

4) Dilarang membawa dan/atau menggunakan perangkat kominikasi elektronik dan optik, kamera, kalkulator, dan sejenisnya ke dalam ruang ujian;

5) Mengumpulkan tas, buku, dan catatan dalam bentuk apapun di bagian depan di dalam ruang kelas;

6) Mengisi daftar hadir dengan menggunakan pulpen yang disediakan oleh pengawas ruangan;

7) Masuk ke dalam (login) sistem menggunakan username dan password yang diterima dari proktor;

8) Mulai mengerjakan soal setelah ada tanda waktu mulai ujian;

9) Selama ujian berlangsung, hanya dapat meninggalkan ruangan dengan izin dan pengawasan dari pengawas ruang ujian;

10) Selama ujian berlangsung, dilarang: Menanyakan jawaban soal kepada siapa pun; Bekerja sama dengan peserta lain; Memberi atau menerima bantuan dalam menjawab soal; Memperlihatkan pekerjaan sendiri kepada peserta lain atau melihat pekerjaan peserta lain; Menggantikan atau digantikan oleh orang lain. 
11) Bagi siswa yang telah selesai mengerjakan soal sebelum waktu ujian berakhir tidak diperbolehkan meninggalkan ruangan sebelum waktu ujian berakhir; Berhenti mengerjakan soal setelah ada tanda waktu ujian berakhir; Meninggalkan ruangan setelah ujian berakhir.

Berdasarkan deskripsi data hasil wawancara dan observasi di atas dapat diambil kesimpulan bahwa sistem dan tata tertib pelaksanaan Ujian Akhir Madrasah Berbasis Android (UAMBA) sepenuhnya sesuai dengan Prosedur Oprasional Standar Penyelenggaraan Ujian Nasional Tahun Pelajaran 2018/2019.

\section{Ketercapaian dari Pelaksanaan Ujian Akhir Madrasah Berbasis Android.}

Setelah terlaksananya Ujian Akhir Madrasah Berbasis Android (UAMBA) tahun ajaran 2018/2019 di Madrasah Ibtidaiyah Negeri 1 Lebong, ada beberapa hal yang dicapai dari pelaksanaan ujian tersebut. Berdasarkan hasil wawancara bersama kepala Madrasah sebagai berikut:

"Sesuai dengan harapan kita, pelaksanaan UAMBA ini memiliki beberapa kelebihan diantaranya; 1) lebih menghemat anggaran, 2) keterlambatan soal UAM bisa diminalisir, 3) meminimalisir kecurangan saat ujian, 4) lebih memudahkan siswa, 5) hasil ujian bisa diketahui dengan cepat. Seperti yang kita ketahui pelaksanaan ujian nasional secara manual membutuhkan biaya yang tidak sedikit, penggunaan anggaran dimulai dari percetakan soal ujian nasional, pendistribusian ujian nasional yang membutuhkan dana yang lumayan besar. Kemudian kita belajar dari kejadian sebelumnya dalam pelaksanaan UAM terkadang terjadi keterlanbatan berkas soal UAM yang menyebabkan jadwal ujian harus diundur. Kecurangan yang kadang dilakukan saat ujian oleh sebagian siswa adalah kebiasaan mencontek lembar jawaban temannya, dengan penerapan sistem ujian nasional berbasis computer membuat hal tersebut sulit Untuk dilakukan karena soal ujiannya di acak, jadi mereka tidak bisa saling mencontek lagi. Kemudian dalam segi kemudahan, bisa dikatakan ujian nasional berbasis Android lebih memudahkan siswa ketimbang ujian nasioanl secara manual/konvensional. Kemudahan tersebut seperti siswa tidak repot lagi mengisi biodata menggunaakan pensil yang harus dilakukan dengan ketelitian dan kesabaran. Hasil ujian bisa diketahui dengan cepat, tidak seperti Ujian Nasioal secara manual yang membutuhkan waktu lama Untuk mengetahui hasil ujian. Ujian Nasional Berbasis Komputer justru sebaliknya, waktu yang dibutuhkan Untuk mengetahui hasil ujian terbilang hanya sebentar karena menerapkan jaringan internet yang terkoneksi dengan server pusat jadi tidak seperti ujian manual yang mesti mengirim 
berkas ujian dulu ke pusat Untuk diperiksa. Alhamdulillah hal ini semua dapat kita capai dengan hasil yang baik". ${ }^{37}$

Pernyataan kepala madrasah tersebut juga disampaikan oleh ibu Jumiati Guru madrasah bidang Madarah Ibtidaiyah Negeri 1 Lebong sebagai berikut:

"Biasanya pada ujian nasional secara manual harus mengeluarkan dana yang besar Untuk pengadaan soal ujian, dan harus menjemput soal ujian dulu, baru bisa melaksanakan ujian. Namun, setalah adanya UAMBA ini semua jadi lebih mudah, tidak perlu menjemput dan menghantarkan soal ke pusat lagi Untuk di periksa, dan hasil ujianpun bisa cepat diketahui." ${ }^{38}$

Salah seorang siswa kelas VI Madrasah Ibtidaiyah Negeri 1 Lebong yang sukup cakap berkomunikasi bernama Aulia menyatakan bahwa: "Dalam pelaksanaan UAMBA ini kami benar-benar harus mengerjakan soal ujian dengan jujur, karena walaupun soal kami sama, harus dijawab sesuai dengan durasi waktu yang telah ditetapkan". ${ }^{39}$ Hasil wawancara ini diperoleh gambaran bahwa proses pelaksanaan Ujian Akhir Madrasah Berbasis Android (UAMBA) ini berjalan sesuai dengan ketentuan yang berlaku, sejatinya UAMBA merupakan sebuah terobosan yang cukup efektif, efesien dan memudahkan berbagai pihak. Hasil yang dicapai setelah melaksanakan Ujian Akhir Madrasah Berbasis Android (UAMBA) adalah menghindari kecurangan nilai, nilai lebih objektif dan dapat menseleksi siswa yang berprestasi Untuk selanjutnya di utus ke sekolah yang bermutu. Artinya ditinjau dari ketercapaian penggunaan media ini pihak sekolah memiliki persepsi yang sama bahwa terjadi kemudahan-kemudahan dalam pelaksanaan ujian baik bagi penyelenggara maupun bagi peserta ujian.

\section{PENUTUP}

Berdasarkan pembahasan dari hasil penelitian yang dilakukan maka dapat diketahui bahwa pelaksanaan Ujian Akhir berbasis Android yang sering dikenal dengan sebutan UAMBA ini dinilai cukup baik karena memiliki beberapa kelebihan diantaranya adalah lebih menghemat anggaran, keterlambatan soal UAM bisa diminalisir, meminimalisir kecurangan saat ujian, lebih memudahkan siswa, hasil ujian bisa diketahui dengan cepat karena pelaksanaan ujian nasional secara manual membutuhkan biaya yang tidak sedikit, penggunaan anggaran dimulai dari percetakan soal ujian nasional, pendistribusian ujian nasional yang membutuhkan dana yang lumayan besar.

\section{DAFTAR PUSTAKA}


Anwar, Saepul, and Agus Fakhruddin. "Pelaksanaan Standar Penilaian Oleh Guru Pendidikan Agama Islam Di Sekolah (Studi Evaluatif Terhadap Guru PAI SMP dan SMA di Bandung)." Jurnal Pendidikan Agama Islam-Taâ€TM Lim 14, no. 2 (2016).

Batubara, M. Diarmansyah, and Evta Indra. "Perencanaan Dan Pembuatan Aplikasi Pengerjaan Ujian Nasional Tingkat SMP Berbasis Android." Query: Jurnal Sistem Informasi 2, no. 02 (2018): 11.

Fadil, Muhammad. "Penerapan Manajemen Berbasis Madrasah (MBM)(Studi Terhadap Karakteristik Input MBM di MIN 4 Pringsewu).” PhD Thesis, UIN Raden Intan Lampung, 2017.

Febrianto, Febrianto, Muhammad Rais, and Nurmila Nurmila. "Analisis Penerapan Media Pembelajaran Prezi Terhadap Hasil Belajar Siswa Kelas X TPHP Pada Mata Pelajaran Pengendalian Mutu Dalam Proses Pengolahan Di SMK Negeri 3 Takalar." Jurnal Pendidikan Teknologi Pertanian 2 (2018): 47-56.

Hajar, Ruyatul. "Implementasi Penjaminan Mutu Pendidikan Dalam Meningkatkan Kinerja Madrasah: Studi Di MTs Assurur Dan MTs Arrohmah Kota Tasikmalaya." Indonesian Journal of Education Management \& Administration Review 1, no. 1 (2018): 89-98.

Hakim, Lukman. "Pemerataan Akses Pendidikan Bagi Rakyat Sesuai Dengan Amanat Undang-Undang Nomor 20 Tahun 2003 Tentang Sistem Pendidikan Nasional." EduTech: Jurnal Ilmu Pendidikan Dan Ilmu Sosial 2, no. 1 (2016).

Hasan, Adtman A., and Umi Baroroh. "Pengembangan Media Pembelajaran Bahasa Arab Melalui Aplikasi Videoscribe Dalam Meningkatkan Motivasi Belajar Siswa." لسـانـا (LISANUNA): Jurnal Ilmu Bahasa Arab Dan Pembelajarannya 9, no. 2 (2020): 140-155.

Hashimov, Elmar. Qualitative Data Analysis: A Methods Sourcebook and The Coding Manual for Qualitative Researchers: Matthew B. Miles, A. Michael Huberman, and Johnny Saldaña. Thousand Oaks, CA: SAGE, 2014. 381 Pp. Johnny Saldaña. Thousand Oaks, CA: SAGE, 2013. 303 Pp. Taylor \& Francis, 2015.

Hidayatullah, Syarif, Ismail Marzuki, and Lukmanul Hakim. "UNBK: Transformasi Sistem Evaluasi Standar Nasional Di Era Revolusi Industri 4.0.” Jurnal Kajian Islam Dan Pendidikan Tadarus Tarbawy 2, no. 1 (2020).

Huzaimah, Fazriani, and Dedy Irfan. "Rancang Bangun Aplikasi Ujian Online Pra Kompre Berbasis Android." VoteTEKNIKA: Jurnal Vocational Teknik Elektronika Dan Informatika 6, no. 2 (2018): 53-60. 
Indrawan, Irjus. "Optimalisasi Politik Pendidikan Nasional Melalui Manajemen Berbasis Sekolah." INNOVATIO: Journal for Religious Innovation Studies 18, no. 1 (2018): 1-14.

Maulida, Khaira, and Wirdanengsih Wirdanengsih. "Upaya Yang Dilakukan Sekolah Di Daerah Terpencil Menghadapi Kebijakan UNBK." Jurnal Perspektif 2, no. 3 (2019): 243-250.

Miles, Matthew B., A. Michael Huberman, and Johnny Saldaña. Qualitative Data Analysis: A Methods Sourcebook. 3rd. Thousand Oaks, CA: Sage, 2014.

Moleong, Lexi J. Methodology of Qualitative Research. Bandung: Remaja Rosda Karya, 2010.

Mubarok, Tyas Alhim. "Pendampingan Persiapan Ujian Akhir Sekolah Pada Mata Pelajaran Bahasa Inggris Di Madrasah Aliyah Darul Muta'állimin Sugihwaras Nganjuk." Jurnal Pengabdian Dan Pemberdayaan Nusantara (JPPNu) 2, no. 1 (2020): 76-81.

Nugraha, Aditya Adjie, Desi Kisbianty, and Benni Purnama. "Aplikasi Simulasi Try Out Ujian Nasional Pada Jurusan Multimedia Berbasis Android Pada SMKN 1 Kuala Tungkal.” Jurnal Ilmiah Mahasiswa Teknik Informatika 2, no. 2 (2020): 137-147.

Pasaribu, Asbin. "Implementasi Manajemen Berbasis Sekolah Dalam Pencapaian Tujuan Pendidikan Nasional Di Madrasah.” EduTech: Jurnal Ilmu Pendidikan Dan Ilmu Sosial 3, no. 1 (2017).

Prajana, Andika, and Yuni Astuti. "Pemanfaatan Teknologi Informasi Dan Komunikasi Dalam Pembelajaran Oleh Guru SMK di Banda Aceh Dalam Upaya Implementasi Kurikulum 2013.” JINOTEP (Jurnal Inovasi Dan Teknologi Pembelajaran): Kajian Dan Riset Dalam Teknologi Pembelajaran 7, no. 1 (2020): 33-41.

Rahmat, Pupu Saeful. "Peran Pendidikan Dalam Menyiapkan Generasi Emas." Pendidikan Guru Sekolah Dasar S1 1, no. 01 (2016).

Roulston, Kathryn. "Analysing Interviews." The SAGE Handbook of Qualitative Data Analysis, 2014, 297-312.

Santi, Mirna, and Andika Prajana. "Analisis Implementasi Ujian Nasional Berbasis Komputer Dengan Ujian Berbasis Kertas Di Smpn 3 Ingin Jaya Kabupaten Aceh Besar." Jurnal Pendidikan Teknologi Informasi 2 (2018): 84-91.

Setyosari, Punaji. Metode Penelitian Pendidikan \& Pengembangan. Prenada Media, 2016.

Suryana, S. "Permasalahan Mutu Pendidikan Dalam Perspektif Pembangunan Pendidikan.” Edukasi 2, no. 1 (2017). 
Warsah, Idi. "Islamic Psychological Analysis Regarding To Rahmah Based Education Portrait At IAIN Curup." Psikis : Jurnal Psikologi Islami 6, no. 1 (June 1, 2020): 29-41. https://doi.org/10.19109/psikis.v6i1.3941.

Warsah, Idi, and Nuzuar Nuzuar. "Analisis Inovasi Administrasi Guru Dalam Meningkatkan Mutu Pembelajaran (Studi Man Rejang Lebong)." Edukasi 16, no. 3 (2018): 294572.

Warsiyah, Warsiyah. "Perilaku Menyontek Mahasiswa Muslim." Wahana Akademika: Jurnal Studi Islam Dan Sosial 2, no. 2 (2016): 31-50.

Yayitarina, Dwi Desi. "Regulasi Pendidikan Nasional Sebagai Upaya Meningkatkan Sumber Daya Manusia Memasuki Era Masyarakat Ekonomi ASEAN (Mea)." Jurnal Yuridis 3, no. 1 (2017): 66-82.

Yusuf, Muri. Metode Penelitian Kuantitatif, Kualitatif \& Penelitian Gabungan. Prenada Media, 2016. 